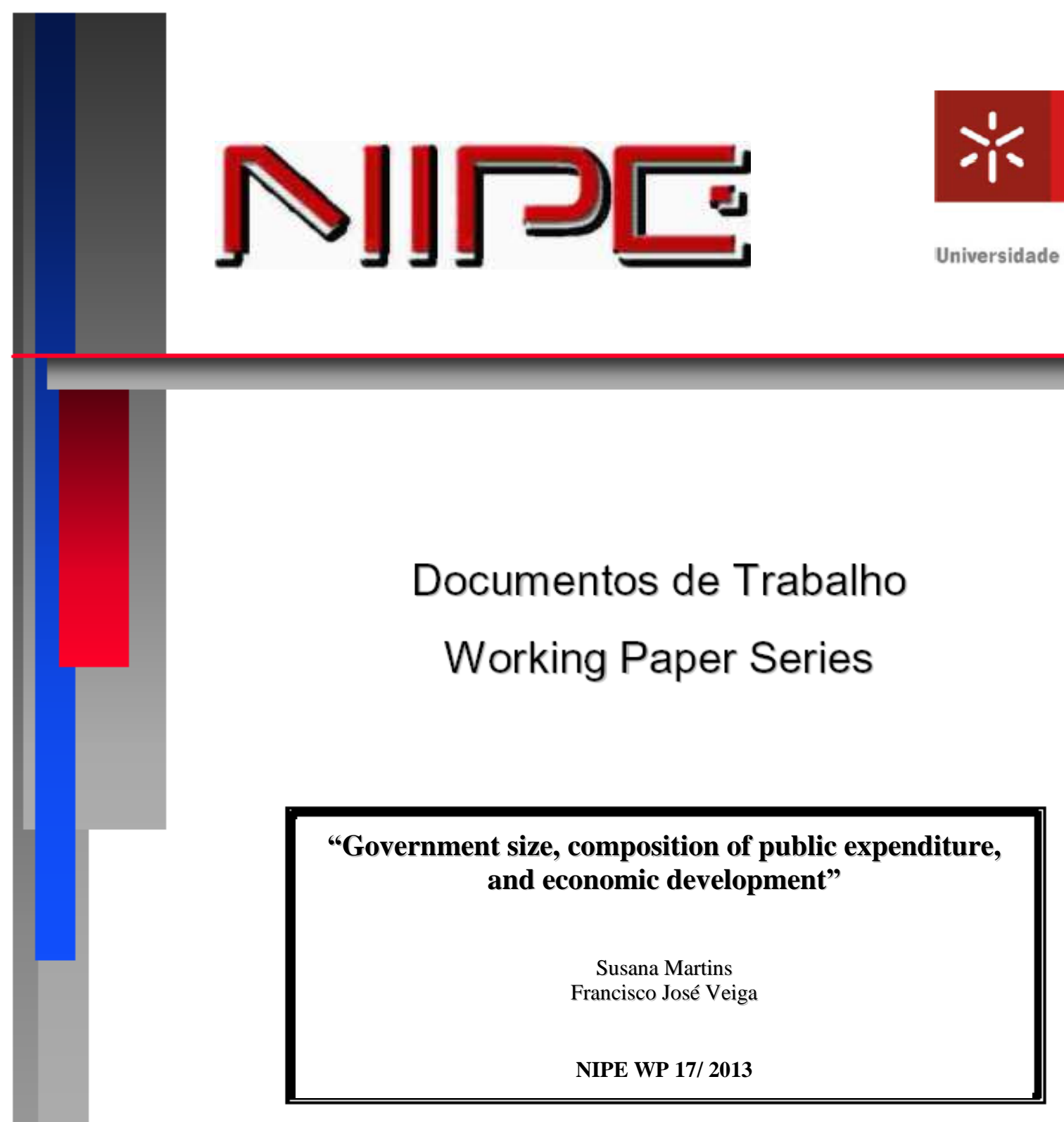

NÚCLEO DE INVESTIGAÇÃO EM POLÍTICAS ECONÓMICAS UNIVERSIDADE DO MINHO 


\section{"Government size, composition of public expenditure, and economic development"}

Susana Martins

Francisco José Veiga

NIPE* WP 17/ 2013

URL:

http://www.eeg.uminho.pt/economia/nipe
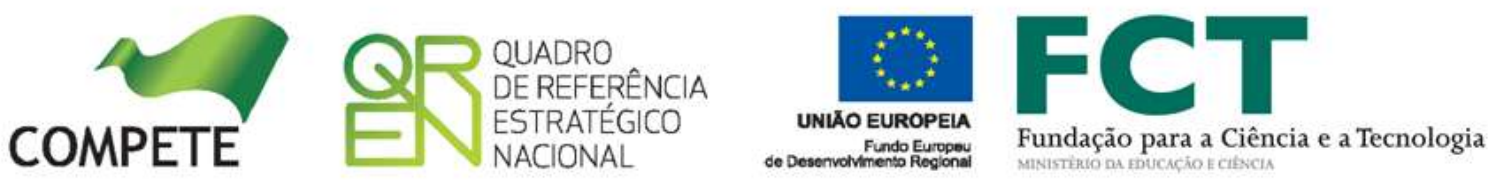


\title{
Government size, composition of public expenditure, and economic development
}

\author{
Susana Martins ${ }^{\text {a }}$, Francisco José Veiga ${ }^{\text {b,* }}$ \\ ${ }^{\mathrm{a}, \mathrm{b}}$ Universidade do Minho and NIPE, Escola de Economia e Gestão, 4710-057 Braga, Portugal. \\ a scmartins@eeg.uminho.pt , b fjveiga@eeg.uminho.pt
}

\begin{abstract}
This paper analyzes the effects of government size and of the composition of public expenditure on economic development. Using the system-GMM estimator for linear dynamic panel data models, on a sample covering up to 156 countries and 5-year periods from 1980 to 2010, we find that government size as a percentage of GDP has a quadratic (inverted U-shaped) effect on the growth rate of the Human Development Index (HDI). This effect is especially pronounced in developed and high income countries. We also find that the composition of public expenditure affects development, with the share of five subcomponents exhibiting non-linear relationships with HDI growth.
\end{abstract}

JEL Classifications: H50, O15, O23, O43

Keywords: Economic Development, Government Size, Composition of public expenditure; Human Development Index

* Corresponding author. Tel.: +351 253604534; fax: +351 253601380. 


\section{Introduction}

How can a country become economically more developed? Why, in 2010, an inhabitant of Liechtenstein lived with $\$ 222$ per day, while a Zimbabwean lived with only $\$ 0.48 ?^{1}$ Why is life expectancy 83 years for a Japanese and only 45 years for an Afghan? In addition to the wide differences between developed and developing countries, there are also dissimilarities within each group of countries. Since among the functions of government are the redistribution of income among citizens and the access of everyone to education and health, differences in the size of government and in the composition of public expenditure across countries may help explain differences in development.

Although the government has grown incredibly and sometimes dramatically in most countries, government size growth is neither a recent phenomenon nor a simple one. Governments must promote social development and economic growth, but it is hard to determine if an increase in public intervention by increasing public spending will have a positive impact on economic performance. Economic growth is necessary for economic development, but income distribution and the economic structure are also determinants of the level of development. Therefore, studying only the impact of public spending on economic growth is a somewhat partial analysis.

There are many studies on the effects of government expenditures on economic growth, but the literature analyzing the effects on economic development is much scarcer. Furthermore, there is a very reduced number of studies examining the growth effects of the composition of public expenditure using samples that cover developing countries and data since the 1970s. This is essentially due to the fact that the historical fiscal data reported to the IMF's Government Finance Statistics follows two different classification standards which are hard to combine. Acosta-Ormaechea and Morozumi (2013) have recently merged GFSM1986 and GFSM2001 to assemble a new dataset which covers the

\footnotetext{
${ }^{1}$ Just over a third of the poverty line of $\$ 125$ per day. Values obtained from UNDP (2011).
} 
period 1970-2010. They then analyze the effects of public expenditure reallocations in long-run economic growth and conclude that increases in the share of education spending tend to be growth-enhancing. ${ }^{2}$

The main objective of the present study is to fill an important gap in the literature by empirically examining the effects of government size and of expenditure composition on economic development. To the best of our knowledge, no previous studies have analyzed the effects of expenditure composition on economic development. We perform system-GMM estimations for a linear dynamic panel data model using a sample that covers up to 156 countries, ${ }^{3}$ for consecutive and non-overlapping 5 -year periods from 1980 to 2010. The dependent variable is the growth rate of the UNCTAD's Human Development Index (HDI) over a 5-year period. Our results indicate that government size has a quadratic (inverted U-shaped) effect on the HDI growth rate, especially in developed and high income countries. Thus, in these countries, excessive government size is detrimental to economic development. Regarding expenditure composition, we find that the shares of defense, education and social protection expense in total public expenditure have U-shaped relationships with development, while health and the group of remaining expenses have inverted U-shaped relationships.

The paper is structured as follows. Section 2 summarizes the literature on government size and economic development, also comprising the literature which relates government size with economic performance. The data and the empirical model are presented in section 3, and the results are shown and discussed in section 4. Finally, the conclusions are presented in section 5.

\footnotetext{
${ }^{2}$ Kneller et al. (1999) empirically analyze the effects of the structure of taxation and public expenditure on economic growth for a sample of 22 OECD countries. They find that distortionary taxation reduces growth, whilst nondistortionary taxation does not, and that productive public expenditure enhances growth, whilst non-productive expenditure does not.

${ }^{3}$ When using data on public expenditure composition, the estimations cover 79 countries.
} 


\section{Government size and economic performance}

\subsection{Government size}

Despite the growth of government in the last fifty years, this is neither a recent nor a simple phenomenon. Government, in greater or lesser extent and clarity, centralized or not, is present in almost all daily activities. It is possible to compare in time and between countries the relative size of governments or even the efficiency of some activities, but it is not possible to say in absolute when there is excessive government. Comparing observations requires some care, especially when comparing over time, as they have to be adjusted to inflation and demographic growth (Ulbrich 2003). The most common and less disadvantageous variable to measure government size is public expenditure ${ }^{4}$ as a percentage of Gross Domestic Product (GDP).

The size and role of government have always been closely linked: changes in the growth of government were related to changes in its role in the economy. Since the late nineteenth century that public expenditures have been increasing considerably, on average, ${ }^{5}$ but more rapidly in the period before 1980 (Peltzman 1980; Tanzi and Schuknecht 2000). It was a protective and welfare state government, seeking for a greater redistribution of income and wealth from the richest to the poorest, playing roles that the markets alone could or would not play, such as the provision of public goods and services and the mitigation of externalities. A growing skepticism about governmental intervention in the economy and the view of the public sector as "excessive" and expensive, and as a welfare state that creates disincentives to private initiative through high taxes, are among the explanations for the slowdown of public expenditure after 1980.

\footnotetext{
${ }^{4}$ Public expenditure is less volatile and less susceptible to measurement errors than public revenue (Labonte 2010).

${ }^{5}$ On average, considering there is an asymmetry in government growth. For example, faster development of public expenditure in less institutionally constrained countries.
} 


\subsection{Economic development}

Because of their strict relationship, economic development is often confused with economic growth (see Pomfret 1997). Actually, they are quite different. Economic development can be defined as a qualitative change and restructuring of a country, reflecting not only technological progress, but also social progress. In turn, economic growth can be defined as a quantitative change in a country's economy, measured by changes in GDP over one year. Nevertheless, despite these differences, GDP and economic growth are the most commonly used indicators of economic development.

Economic growth is necessary but not sufficient for economic development: the income distribution and economic structure are also examples of essential indicators of economic development (Nafziger 2006). It is not correct to say that a country has developed economically just because its GDP per capita has increased, when a great part of the population still lives in precarious conditions. For Seers (1969), the income level only represents the potential for economic development; to register economic development it is essential to verify reductions of poverty, unemployment and inequality in a country. That is, a country may be rich but not necessarily developed.

Defining and measuring economic development is still a problem that generates as much controversy as measuring government size. There isn't a proper measure, but some that may be more plausible and acceptable than others. Faced with this measurement problem, several alternatives were developed to measure the welfare of a population, combining several indicators of economic development. The most commonly accepted is the Human Development Index (HDI). The HDI was first developed by the United Nations Development Program (UNDP) in 1990, stating that the differences between developed and developing countries were smaller when measured by human development than by the simple comparison of per capita income. According to the Human Development Report 
(UNDP 2011), this is a summary index that results from the geometric mean ${ }^{6}$ of three basic dimensions of human development: (1) long and healthy life, (2) access to knowledge and education, and (3) decent and stable living standards. To each of the indices included, the maximum value (observed) and minimum value (observed or not) are assigned, resulting in the index value ${ }^{7}$ for each country $i$ in year $t$ as explained in the Appendix.

The HDI also presents some limitations, such as scaling index values between 0 and 1, the weight assigned to each of the basic dimensions, or difficulties encountered when comparing countries by other factors related to the enrollment rate, such as quality of schools or dropout rates, which vary substantially from year to year. Nevertheless, Nafziger (2006) considers that the HDI is better, more complete and multifaceted than any other indicator or index, being useful for the qualitative aspects of development, influencing countries with low levels of development to review their policies of nutrition, health and education. In this sense, the HDI is the indicator used in the present study to compare countries regarding their levels of development.

\subsection{Effects on economic growth and development}

Since economic growth is a common indicator of economic development, it is important to take the impact of government size on economic growth into account. This literature is immense, as many authors dedicated attention to it and found a variety of results. Therefore, we describe only a small part of the existing literature.

\footnotetext{
${ }^{6}$ The authors argue for the replacement of the arithmetic mean (used in previous reports) by the geometric mean because the values obtained for the indices are lower, occurring major changes only for countries where there is a greater inequality between the dimensions of development.

${ }^{7}$ As these maximum and minimum values vary over time, every year all indexes for all countries are recalculated. Hence, for temporal consistency, comparisons should not be made using different publications of the UNDP for the HDI. Thus, all HDI data used in this paper comes from UNDP (2011).
} 
An important empirical study was that of Barro (1991). Despite the difficulties in measuring public services and growth rates, or in treating government size as an endogenous variable, for a relatively low level of productive public expenditure, ${ }^{8}$ he finds that government size positively influences economic growth. From a certain (optimum) level on, increasing government size has a negative impact. ${ }^{9}$ Barro also concluded that for a given value of the government size, an increase in unproductive expenditure leads to a decrease in growth rates and saving; despite not having a direct impact on productivity in the private sector, the increase in income leads to a tax disincentive to investment. These empirical results are consistent with his analysis of government spending in an endogenous growth model (Barro 1990). ${ }^{10}$ Easterly and Rebelo (1993) find that fiscal policy is influenced by the scale of the economy and that investment in transport and communication is consistently correlated with growth.

According to Gwartney et al. (1998), channeling resources from the free functioning private markets to the public sector implies higher taxes that create disincentives for workers and investment, inefficiency, low returns, and lack of dynamics and innovation in the political process (when compared to the market process). These effects may even dominate and generate a negative impact on growth. Furthermore, there is no reason to expect that most goods can be allocated or provisioned more efficiently by the public

\footnotetext{
${ }^{8}$ Corsetti and Roubini (1996), in their study of the effects of government expenditure in endogenous growth models, ensure that many forms of public expenditure are directly or indirectly productive affecting productivity in different ways.

${ }^{9}$ Labonte (2010) also highlighted the need to distinguish fluctuations in short-term growth, resulting from economic cycles, from sustainable long term growth rates. The four action forms of the public sector (spending, transfers, taxes and regulation) have the potential to influence long-term growth through labor supply, physical capital and productivity. Tanzi and Zee (1997) concluded that, by using public financial instruments, tax policy can play a fundamental role in the performance and long-term growth of countries.

${ }^{10}$ For other theoretical models analyzing the effects of public expenditure on economic growth see, among others, King and Rebelo (1990), Lucas (1988), and Meltzer and Richard (1981).
} 
sector than by the private sector. ${ }^{11}$ Other works such as those of Barro and Sala-i-Martin (1995), Bassanini et al. (2001), Fölster and Henrekson (1999) and Heitger (2001) found empirical evidence of a negative and statistically significant effect on economic growth, using general public expenditure. Similarly, Fölster and Henrekson (2001), with an analysis for industrial countries (OECD), obtained strong, robust and statistically significant results for a negative effect of total public expenditure on economic growth, but not statistically significant for the negative effect of taxes. Afonso and Furceri (2010) found that the impact of public expenditure and revenue on economic growth (measured by the growth rate of per capita real GDP), was negative, substantial, and statistically significant.

Although they are closely related, the variables that affect economic growth may not affect (or affect differently) economic development, given the qualitative nature of the latter, which also considers dimensions such as longevity and education. In an attempt to find the optimal size of government (public spending on consumption and investment, as a percentage of GDP), Davies (2009) concluded that the optimum level of government size would be higher for economic development (using HDI) than for economic growth (using GDP). His results also indicate that: (1) for all countries and relatively low government size, there is a positive relationship between expenditure on consumption and investment and changes in the HDI. Above the optimum government size, the relationship would be negative; (2) in a symmetric way, for countries of high income, but with low values of government size, the relationship would be negative. Going beyond the optimum point (in this case the minimum point), then the relationship would be positive. ${ }^{12}$ Yavas (1998) argued that this relationship is due to the strong need for provision of infrastructure and

\footnotetext{
${ }^{11}$ See also Hauner and Kyobe (2010) and Afonso, Schuknecht and Tanzi (2005), who empirically analyzed the efficiency and performance of the public sector, finding evidence of a negative relationship between these indicators and government size.

${ }^{12}$ The functions representing (1) and (2) have, respectively, downward and upward concavity.
} 
public services in countries with low development, hence benefiting more of an expansion in public spending. According to these authors, different effects are expected for countries with high and low development and with high and low income.

Mourmouras and Rangazas (2009) developed an overlapping generations model and concluded that countries where the government is less democratic or more elitist, benefiting landlords, who are richer, will face higher tax rates and slower growth. They confirmed their hypothesis through a quantitative analysis which indicated that, for lower stages of development, high taxes and public consumption may slow down economic growth and development. They do not deny, however, a positive association between high taxes and growth if there is at the same time large public investment. The authors also suggested that, as a country develops over time, the natural tendency is for an increasing government size.

\section{Data and econometric model}

To estimate the proposed model, we use a panel data base, with a cross-sectional component of up to 156 countries and a temporal component covering the period from 1980 to 2010 , for a wide range of variables.

\subsection{The data}

The availability of repeated observations (years) for the same units (countries) on the basis of panel data allows us to specify and estimate more complex and realistic models. However, they also have some practical disadvantages, as it is no longer appropriate to assume that the different points are independent, hampering analysis, particularly for nonlinear and dynamic models (Verbeek, 2008).

Many advantages are taken into account by choosing panel data for smaller periods of observation, especially in studies like this which include fiscal policy variables. Fölster 
and Henrekson (2001) argue that using longer periods (30 or 40 years) makes it less effective to capture the effects on growth, increases the difficulty in eliminating the effect of economic cycles, or the demographic influence on government size or on GDP growth. Afonso and Furceri (2010) also add that the information on the variation of growth or government size in a country is lost and dummies for each period or country should be used for their ability to capture these specific effects of each period or country. Furthermore, as the HDI is constructed and available for periods of five years, ${ }^{13}$ in the present study the temporal section shall consist of six consecutive and non-overlapping 5year periods between 1980 and 2010 .

The dependent variable used is the growth rate of the Human Development Index (HDI), provided by the Human Development Report (UNDP 2011):

- HDI_GR $\mathrm{i}_{\mathrm{i}, \mathrm{t}}$ : HDI annual average growth rate for country $\mathrm{i}$ in period $\mathrm{t}$. It is calculated as the logarithmic change between two consecutive periods.

The explanatory variables included in the baseline model are the initial level of HDI and variables that represent government size, investment, health and education.

- $\mathrm{HDI}_{\mathrm{i}, \mathrm{t}-1}$ : $\log$ of HDI for country i period $\mathrm{t}-1$. Assuming that conditional development convergence among countries occurs, a negative coefficient is expected for initial HDI.

- SIZE $_{\mathrm{i}, \mathrm{t}}$. Size of government: average government expenditure as a percentage of GDP for country i and period t. Sources: United Nations and PWT 7.0 (Heston et al. 2011).

- $\mathrm{SIZE}_{\mathrm{i}, \mathrm{t}}{ }^{2}$. Size of government squared: It is introduced to catch the quadratic effect of government size growth on HDI. A negative coefficient is expected, as an excessive size of government will be detrimental to the private sector, to economic growth and, consequently, to economic development.

\footnotetext{
${ }^{13} \mathrm{HDI}$ is available for periods of five years between 1980 and 2000. Only since 2000 (inclusive) till 2010 it is provided annually,
} 
- Investment growth gro $_{\text {: }}$ growth rate of domestic investment. A positive coefficient is expected, as a higher growth rate of investment should lead to higher GDP growth rates and to higher development. Source: PWT 7.0, National Accounts file, variable ikon.

- Infant mortality ${ }_{i t}$ : Infant (under 5 years old) mortality rate (per thousand births). This variable is a proxy of the quality of the health system. A negative coefficient is expected, as higher infant mortality rates reflect lower quality of the health system. Source: WDI, World Bank.

- Secondary school enrollment ${ }_{i t}$ : Total enrollment in secondary education, regardless of age, expressed as a percentage of the population of official secondary education age. Since greater enrollment rates lead to a more educated population, it should also lead to greater levels of human development. Thus, a positive coefficient is expected. Source: WDI, World Bank.

Except for the initial HDI level, 5-year period averages of the explanatory variables will be used in the estimations. ${ }^{14}$ The descriptive statistics are summarized in Table 1.

\section{[Insert Table 1 about here]}

\subsection{Econometric model}

Since the HDI in any period is similar to that of the previous period, we estimate a dynamic model, allowing for the quadratic impact of government size:

$$
\begin{aligned}
& \text { HDI_GR }{ }_{i, t}=\alpha_{i}+\beta H_{i, t-1}+\gamma_{1} \operatorname{SIZE}_{i, t}+\gamma_{2} \operatorname{SIZE}_{i, t}{ }^{2}+\theta_{k} X+\gamma_{t}+u_{i, t} \\
& i=1,2,3, \ldots 163 \text { countries } \\
& t=1,2,3, \ldots, 7 \text { non-overlapping periods of five years: 1976-80, 1981-85, 1986-90, } \\
& 1991-95,1996-2000,2001-05 \text { and 2006-10. } \\
& \alpha_{i} \text { : individual specific effect }
\end{aligned}
$$

\footnotetext{
${ }^{14}$ Since life expectancy and years of education are used in the computation of the HDI, we use alternative indicators of health (infant mortality) and education (secondary school enrollment).
} 


\section{$\theta_{\mathrm{k}} \mathrm{X}$ : matrix of $\mathrm{k}$ explanatory variables}

$\gamma_{\mathrm{t}}$ : fixed effect for period $\mathrm{t}$ (one dummy variable for each period)

$\mathrm{u}_{\mathrm{i}, \mathrm{t}}:$ error term

According to Arellano and Bond (1991), the conditions of moments approach may be used to estimate a dynamic model from a panel data base ${ }^{15}$ more consistently and efficiently. This is known as the Generalized Method of Moments (GMM). Taking first differences of (1), levels of the explanatory variables may be used as instruments to avoid correlation between lagged variables and the country specific effect. For this difference GMM estimator to be consistent, it must be ensured that there is no autocorrelation in the errors and no correlation between individuals in residuals. When $\mathrm{N}$ is large, a binary variable, one for each period, should be included to avoid this problem.

Arrelano and Bover (1995) and Blundell and Bond (1998) also suggested additional moment conditions, ${ }^{16}$ since, as long as valid, they increase the efficiency of the estimators. This GMM estimator which combines the moment conditions of the model in first differences and those of the model in levels (differences are used as instruments for the level equations), is known as system-GMM. This allows estimating with lower bias and higher accuracy (Bond, 2002).

\section{Results}

The results of system-GMM estimations of the baseline model are shown in Table 2. Since all explanatory variables, except the period dummies, may be affected by economic development, they were treated as endogenous. Two-step results using robust standard errors corrected for finite samples are reported, $t$-statistics are in parenthesis, the significance level is indicated with stars, and

\footnotetext{
${ }^{15}$ Two problems are associated with these models and should be taken into account: autocorrelation due to the existence of a lagged dependent variable and the presence of a specific effect for each country.

${ }^{16}$ These can be obtained assuming the presence of stationarity of the dependent variable (the variable is convergent) and the lack of correlation between first differences of the instruments and the specific effects.
} 
the number of observations and countries, and the p-values of the Hansen and autocorrelation tests are reported in the bottom part of the table. Finally, the variable that was used as proxy for the size of government in each estimation is indicated at the top of the respective column. ${ }^{17}$

\section{[Insert Table 2 about here]}

The empirical results reported in column 1 indicate that, according to our expectations, the size of government has a quadratic effect on the HDI. There is a positive effect for moderate sizes of government, but after a certain point the effect begins to be negative. Concretely, government expenditure will have a positive impact on development until it reaches 17 percent of GDP. From then on, further increases in government size will have a negative effect on development. Regarding the other explanatory variables, investment growth and secondary school enrollment have positive effects, while infant mortality has a negative effect on the growth rate of the human development index. These results conform to our expectations, since more investment is associated with higher economic growth, secondary school enrollment with more education, while infant mortality is associated with worse health and living conditions. Finally, since some of the period dummies are statistically significant, they must be included in the model.

Since the results could be affected by the choice of the variable that represents the size of government, two other proxies were used in the estimations of columns 2 and 3 . The results are very similar to those of column 1, as there is evidence of a quadratic effect of the size of government on the growth rate of the human development index. The results for the control variables are also similar to those of column 1. Finally, the p-values of the Hansen and autocorrelation tests reported at the bottom part of the table indicate that the instrument

\footnotetext{
${ }^{17}$ UN: General government final consumption expenditure (\% GDP). Source: National Accounts Estimates of Main Aggregates, United Nations Statistics Division.

PWT-kg: Government Consumption Share of PPP Converted GDP Per Capita at 2005 constant prices. Source: PWT 7.0, main file, variable $\mathrm{kg}$.

PWT-NA: Sum of government collective consumption expenditure and government individual consumption expenditure, i.e. gckon plus health and education services of Government consumed by households. (at constant prices). Source: PWT 7.0, National Accounts file, variable gkon.
} 
set is valid and that there is no second order autocorrelation of the residuals. Thus, the results of the system-GMM estimations reported in Table 2 are valid.

It is possible that the impact of the size of government on the growth rate of the human development index in a given country depends on the level of development or of income that it has reached. In order to account for that possibility, the size of government was interacted with the following dummy variables:

- Developed $d_{i t}$ : Dummy variable that equals 1 for countries classified by the UNDP as of high or very high development, and equals zero otherwise.

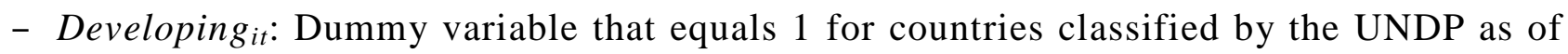
medium or low development, and equals zero otherwise.

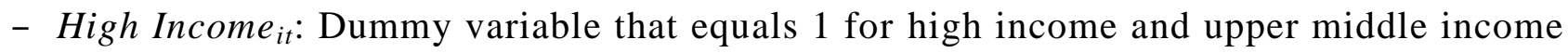
countries (according to the World Bank), and equals zero otherwise.

- Low Income $_{i t}$ : Dummy variable that equals 1 for low income and lower middle income countries (according to the World Bank), and equals zero otherwise.

The results presented in columns 1 and 2 of Table 3 indicate that the quadratic effect found in the estimations of Table 2 may be present only in developed countries. In fact, while both the linear and the quadratic terms of the interactions of the size of government with the dummy variable for developed countries are always statistically significant, the interactions are not statistically significant for developing countries. In the estimations of columns 3 and 4, the size of government was interacted with dummy variables for high and low income countries. The quadratic effect (inverted U-shaped relationship) is present for high income countries. Regarding low income countries, no effects seem to be present in the estimation of column 3 , while there is evidence of a quadratic, U-shaped, effect in column 4. That is, the size of government seems to have opposite effects in high and low income countries, a result that is consistent with those of Davies (2009).

[Insert Table 3 about here] 
There are many studies indicating that institutional quality matters for economic growth (e.g., North 1990, Hall and Jones 1999, and Acemoglu et al. 2005). Since economic growth leads to higher levels of GDP per capita, which are considered in the computation of the HDI, we expect that institutions are also among the determinants of HDI growth. That hypothesis is taken into account in the estimations whose results are reported in Table 4, where four main areas of the Index of Economic Freedom (Gwartney and Lawson 2012) were considered. The results indicate that access to sound money (column 2), freedom to trade internationally (column 3), and more business friendly regulations of credit, labor and business (column 4) are associated with higher rates of human development growth. ${ }^{18}$ Thus, the results shown in Table 4 support the hypothesis that institutions matter for economic development, and they also provide additional evidence of a quadratic effect of government size (both the linear and the quadratic terms are always statistically significant and have the expected signs).

\section{[Insert Table 4 about here]}

Using a new dataset on the composition of public expenditure, assembled by AcostaOrmaechea and Morozumi (2013), which merges the historical fiscal data reported to the IMF's Government Finance Statistics (GFS) under GFSM1986 and GFSM2001, from 1970 to 2010 , we are able to take into account the functional composition of public expenditure, at the central government level, in the estimations of Table 5. Concretely, in each estimation, the share of a subcomponent in total government expenditure was considered, along with the control variables. The subcomponents considered were: defense; health; education; social protection; and the rest (which aggregates the shares of the remaining

\footnotetext{
${ }^{18}$ Since Area 1 of the Index of Economic Freedom is related to the size of government, which was already accounted for in the estimations, only the other four areas were considered in the estimations of Table 4 . It is somewhat surprising that the legal structure and security of property rights does not seem to affect economic development.
} 
subcomponents). Although further disaggregation would be possible, it would come at the cost of losing many observations.

\section{[Insert Table 5 about here]}

The results indicate that larger shares of expenditure in health would foster HDI growth, while the shares of the other subcomponents do not seem to affect HDI growth. The positive coefficient of health expenditure was expected, as it is associated with life expectancy, which is considered in the calculation of the HDI. The lack of results for the other expenditure subcomponents is somewhat surprising. But, it may be due to the fact that we are not accounting for the possibility that they affect HDI growth in a non-linear way. That is, as happened with government size, the subcomponents of expenditure may have a quadratic effect on HDI growth.

That possibility is accounted for in the estimations of Table 6. Now, there is evidence of quadratic effects for all subcomponents. Defense (column 1), education (column 3) and social protection expenditure (column 4) have inverted U-shaped relationships with HDI growth, with optimal (maximum) shares at 13.9, 11.4 and 26.4 percent, respectively. Thus, increases beyond these levels would be detrimental to economic development. On average, that seems to be already the case of social protection expenditure, whose sample average of 28.6 percent is already above the optimal level. Health and the remaining expenditure have U-shaped relationships with HDI growth, with minimum levels at 12.3 and 49.3 percent of total government expenditure, respectively. Thus, increases beyond these levels would promote economic development.

\section{[Insert Table 6 about here]}

\section{Conclusions}

This paper empirically analyzes the effects of government size and of the composition of public expenditure on economic development. To the best of our knowledge, no 
previous studies have analyzed the effects of expenditure composition on economic development and only a few studied the impact of government size. Thus, this paper's main contribution is to fill an important gap in the literature by providing empirical results which may help policymakers promote their countries' economic development.

We use the system-GMM estimator for linear dynamic panel data models on a sample that covers up to 156 countries, for consecutive and non-overlapping 5-year periods from 1980 to 2010. The dependent variable is the growth rate of the UNDP's Human Development Index (HDI) over a 5-year period. Our results indicate that government size has a quadratic (inverted U-shaped) effect on the HDI growth rate, especially in developed and high income countries. Thus, in these countries, excessive government size is detrimental to economic development. Regarding expenditure composition, we find that the shares of defense, education and social protection expense in total public expenditure have U-shaped relationships with development, while health and the aggregated remaining expenses have inverted U-shaped relationships. The latter may result from the fact that those remaining expenditures include transport and communication, which is generally regarded as productive and growth-inducing expenditure.

\section{Acknowledgements}

The authors wish to thank Atsuyoshi Morozumi and participants at the 2013 Congress of the International Institute of Public Finance for very helpful comments, and Atsuyoshi Morozumi and Santiago Acosta-Ormaechea for sharing their data on the composition of public expenditure. The authors are also thankful for the financial support provided by ERDF funds through the Operational Program Factors of Competitiveness - COMPETE and by the Portuguese Foundation for Science and Technology (FCT) under research grant PEst-C/EGE/UI3182/2011. 


\section{REFERENCES}

Acemoglu, D., Johnson, S. and Robinson, J. (2005). Institutions as the fundamental cause of long-run growth. In Aghion, P. e Durlauf, S. (eds.) Handbook of Economic Growth, 385-472. Elsevier, Amsterdam, The Netherlands.

Acosta-Ormaechea, S. and Morozumi, A. (2013). Can a government enhance long-run growth by changing the composition of public expenditure? IMF Working Paper WP/13/162.

Afonso, A. and Furceri, D. (2010). government Size Composition, Volatility and Economic Growth. European Journal of Political Economy, 26, 517-532.

Afonso, A., Schuknecht, L. and Tanzi, V. (2005). Public Sector Efficiency: An international comparison. Public Choice, 123, 321-347.

Arellano, M. and Bond, S. (1991). Some Tests of Specification for Panel Data: Monte Carlo Evidence and an Application to Employment Equations. Review of Economic Studies, 58: 277-297.

Arellano, M. and Bover, S. R. (1995). Another look at the instrumental variable estimation of errorcomponents models. Journal of Econometrics, 68: 29-51.

Barro, R. (1990). Government Spending in a Simple Model of Endogenous Growth. Journal of Political Economy, 98(5), S103-S125.

Barro, R. (1991). Economic Growth in a cross section of countries. Quarterly Journal of Economics, 106, 407-443.

Barro, R. and Sala-i-Martin, X. (1995). Economic Growth. New York: McGraw-Hill.

Bassanini, A., Scarpetta, S. and Hemmings, P. (2001). Economic Growth: the role of policies and institutions. Panel Data evidence from OECD countries. OECD Economics Department Working Paper 283.

Blundel, R. and Bond, S. (1998). Initial conditions and moment restrictions in dynamic panel data models. Journal of Econometrics, 87: 115-143.

Bond, S. (2002). Dynamic panel data models: a guide to micro data methods and practice . Portuguese Economic Journal 1: 141-162.

Corsetti, G. and Roubini, N. (1996). Optimal government Spending and Taxation in Endogenous Growth Models. NBER Working Paper 5851. 
Davies, A. (2009). Human development and the optimal size of government. The Journal of SocioEconomics, 38, 326-330.

Easterly, W. and Rebelo, S. (1993). Fiscal policy and economic growth: An empirical investigation. Journal of Monetary Economics 32(3), 417-458.

Fölster, S. and Henrekson, M. (1999). Growth and the Public Sector: A Critique of the Critics. European Journal of Political Economy, Volume 15, 337-358.

Fölster, S. and Henrekson, M. (2001). Growth effects of government expenditure and taxation in rich countries. European Economic Review, 45(8), 1501-1520.

Gwartney, J. and Lawson, R. (2012). Economic Freedom of the World - 2012 Annual Report. Fraser Institute, Vancouver, BC.

Gwartney, J., Lawson, R. and Holcombe, R. (1998). The Size and Functions of government and Economic Growth. Washington: Joint Economic Committee Study.

Hall, R. and Jones, C., 1999. Why do some countries produce so much more output per worker than others? Quarterly Journal of Economics 114, 83-116.

Hauner, D. and Kyobe, A. (2010). Determinants of government Efficiency. World Development, $38(11), 1527-1542$.

Heitger, B. (2001). The Scope of government and Its Impact on Economic Growth in OECD Countries. Kiel Working Paper No. 103.

Heston, A., Summers, R. and Aten, B. (2011). Penn World Table Version 7.0. University of Pennsylvania: Center for International Comparisons of Production, Income and Prices.

King, R. and Rebelo, S. (1990). Public Policy and Economic Growth: Developing Neoclassical Implications. The Journal of Political Economy, 98(5), 126-150.

Kneller, R., Bleaney, M. and Gemmel, N. (1999). Fiscal policy and growth: evidence from OECD countries. Journal of Public Economics 74, 171-190

Labonte, M. (2010). The Size and Role of government: Economic Issues. CRS Report for Congress. RL 32162.

Lucas, R. (1988). On the mechanics of economic development. Journal of Monetary Economics, $22,3-42$. 
Meltzer, A. and Richard, S. (1981). A Rational Theory of the Size of government. The Journal of Political Economy, 89(5), 914-927.

Mourmouras, A. and Rangazas, P. (2009). Fiscal Policy and Economic Development. Macroeconomic Dynamics 13(4), 450-476.

Nafziger, E. W. (2006). Economic Development. New York: Cambridge University Press.

North, D. (1990). Institutions, Institutional Change and Economic Performance. Cambridge University Press, Cambridge, UK.

Peltzman, S. (1980). The Growth of government. Journal of Law and Economics, 23(2), 209-287.

Pomfret, R. (1997). Development Economics. Hertfordshire: Prentice Hall Europe.

Seers, D. (1969). The Meaning of Development. International Development Review, 11(4), 3-4.

Tanzi, V. and Schuknecht, L. (2000). Public Spending in the 20th Century. Cambridge: The Press Syndicate of the University of Cambridge.

Tanzi, V. and Zee, H. (1997). Fiscal Policy and Long-Run Growth. IMF Staff Papers, 44(2), 179209.

Ulbrich, H. (2003). Public Finance: in Theory and Practice. Mason Ohio: Thomson.

UNDP - United Nations Development Program (2011). Human Development Report. New York: UN.

Verbeek, M. (2008). A Guide to Modern Econometrics ( $3^{\mathrm{a}}$ ed.). Chichester: John Wiley and Sons, Ltd.

Yavas, A. (1998). Does too much government investment retard the economic development of a country? Journal of Economic Studies, 25(4), 296-330. 


\section{APPENDIX}

Human Development Index $(\mathrm{HDI})_{\mathrm{it}}=\sqrt[3]{\mathrm{GNII}_{\mathrm{it}} \times \mathrm{LEI}_{\mathrm{it}} \times \mathrm{EI}_{\mathrm{it}}}$

Gross National Income Index ${ }_{\mathrm{it}}(\mathrm{GNII})=\frac{\ln \left(\mathrm{GNIpc}_{\mathrm{it}}\right)-\ln (\mathrm{GNIpc} \text { min observed })}{\ln (\mathrm{GNIpc} \text { max observed })-\ln (\text { GNIpc min observed })}$

$$
=\frac{\ln \left(\mathrm{GNIpc}_{\mathrm{it}}\right)-\ln (163)}{\ln (108211)-\ln (163)}
$$

Life Expectancy Index it $(\mathrm{LEI})=\frac{\text { Life Expenctancy at } \text { Birth }_{\text {it }}-20}{83.2-20}$

Education Index ${ }_{i t}(\mathrm{EI})=\frac{\sqrt{\mathrm{MYSI}_{\text {it }} \times \mathrm{EYSI}_{\mathrm{it}}}-0}{0.951-0}$

Mean Years of Schooling Index ${ }_{i t}($ MYSI $)=\frac{\text { Mean Years of Schooling } \text { it }-0}{13.2-0}$

Expected Years of Schooling Index ${ }_{\mathrm{it}}(\mathrm{EYSI})=\frac{\text { Expected Years of Schooling }_{\mathrm{it}}-0}{20.6-0}$ 
Table 1: Descriptive Statistics

\begin{tabular}{|c|c|c|c|c|c|}
\hline Variable & Observations & Mean & $\begin{array}{l}\text { Standard } \\
\text { Deviation }\end{array}$ & Minimum & Maximum \\
\hline HDI growth rate & 618 & .009 & .008 & -.047 & .073 \\
\hline $\log (\mathrm{HDI})(-1)$ & 618 & -.588 & .376 & -180 & -.070 \\
\hline Size of government (UN) & 610 & .156 & .064 & .025 & .729 \\
\hline Size of government (PWT-KG) & 618 & .105 & .059 & .026 & .620 \\
\hline Size of government (PWT-NA) & 618 & .153 & .193 & .014 & .860 \\
\hline Investment growth & 618 & -.016 & .129 & -.686 & .951 \\
\hline Infant mortality & 618 & 54.491 & 60.277 & 3.000 & 310.500 \\
\hline Secondary school enrollment & 618 & 67.707 & 32.658 & 2.984 & 155.578 \\
\hline \multicolumn{6}{|l|}{ Area 2: Legal structure and security } \\
\hline of property rights & 512 & 5.909 & 1.983 & 1.143 & 9.624 \\
\hline Area 3: Access to sound money & 525 & 7.738 & 1.579 & 1.213 & 9.838 \\
\hline \multicolumn{6}{|l|}{ Area 4: Freedom to trade } \\
\hline internationally & 504 & 6.730 & 1.829 & 0.000 & 9.565 \\
\hline \multicolumn{6}{|l|}{ Area 5: Regulation of credit, labor, } \\
\hline and business & 523 & 6.263 & 1.096 & 2.615 & 8.781 \\
\hline Defense (\% T.Expense) & 237 & .074 & .061 & .007 & .377 \\
\hline Health (\% T.Expense) & 237 & .091 & .056 & .005 & .248 \\
\hline Education (\% T.Expense) & 237 & .113 & .055 & .016 & .246 \\
\hline Social Protection (\% T.Expense) & 237 & .286 & .156 & .006 & .622 \\
\hline Rest (\% T.Expense) & 237 & .434 & .139 & .206 & .848 \\
\hline
\end{tabular}

Sources: Acosta-Ormaechea and Morozumi (2013), Gwartney and Lawson (2012), PWT 7.0 (Heston et al. 2011), UNDP (2011), World Development Indicators (World Bank). 
Table 2: Government size and Economic Development

\begin{tabular}{|c|c|c|c|}
\hline VARIABLES & $\begin{array}{l}\text { (1) } \\
\text { UN }\end{array}$ & $\begin{array}{c}(2) \\
\text { PWT-kg }\end{array}$ & $\begin{array}{c}(3) \\
\text { PWT-NA }\end{array}$ \\
\hline $\log (\mathrm{HDI})(-1)$ & $\begin{array}{c}-0.0590 * * * \\
(-4.607)\end{array}$ & $\begin{array}{c}-0.0630 * * * \\
(-5.090)\end{array}$ & $\begin{array}{c}-0.0611 * * * \\
(-3.934)\end{array}$ \\
\hline Size of government & $\begin{array}{l}0.138^{*} \\
(1.862)\end{array}$ & $\begin{array}{l}0.136^{*} \\
(1.717)\end{array}$ & $\begin{array}{c}0.0117 * \\
(1.958)\end{array}$ \\
\hline Size of government ${ }^{2}$ & $\begin{array}{l}-0.404 * * \\
(-2.032)\end{array}$ & $\begin{array}{l}-0.431 * * \\
(-2.007)\end{array}$ & $\begin{array}{c}-0.00487 * \\
(-1.776)\end{array}$ \\
\hline Investment growth & $\begin{array}{c}0.0135 * * \\
(2.332)\end{array}$ & $\begin{array}{l}0.0113 * * \\
(2.472)\end{array}$ & $\begin{array}{l}0.0190 * * * \\
(3.823)\end{array}$ \\
\hline Infant mortality & $\begin{array}{c}-0.000197 * * * \\
(-3.036)\end{array}$ & $\begin{array}{c}-0.000209 * * \\
(-2.527)\end{array}$ & $\begin{array}{c}-0.000191 * * \\
(-2.408)\end{array}$ \\
\hline $\begin{array}{l}\text { Secondary school } \\
\text { enrollment }\end{array}$ & $\begin{array}{l}0.000184 * * \\
(2.327)\end{array}$ & $\begin{array}{l}0.000191 * * \\
(2.544)\end{array}$ & $\begin{array}{c}0.000210 * * * \\
(2.792)\end{array}$ \\
\hline Period 2 & $\begin{array}{l}0.00258 * \\
(1.839)\end{array}$ & $\begin{array}{c}0.00127 \\
(0.881)\end{array}$ & $\begin{array}{l}0.00325 * * \\
(2.425)\end{array}$ \\
\hline Period 3 & $\begin{array}{c}0.000899 \\
(0.663)\end{array}$ & $\begin{array}{l}2.68 \mathrm{e}-05 \\
(0.0214)\end{array}$ & $\begin{array}{l}0.00115 \\
(0.971)\end{array}$ \\
\hline Period 4 & $\begin{array}{l}0.00255^{* *} \\
(2.451)\end{array}$ & $\begin{array}{l}0.00170 \\
(1.473)\end{array}$ & $\begin{array}{l}0.00315^{* * *} \\
(3.412)\end{array}$ \\
\hline Period 5 & $\begin{array}{l}0.00191 * * \\
(2.245)\end{array}$ & $\begin{array}{l}0.00128 \\
(1.272)\end{array}$ & $\begin{array}{l}0.00327 * * * \\
(4.056)\end{array}$ \\
\hline Period 6 & $\begin{array}{l}0.00169 * * \\
(2.047)\end{array}$ & $\begin{array}{l}0.00167 * * \\
(2.046)\end{array}$ & $\begin{array}{l}0.00343 * * * \\
\quad(5.341)\end{array}$ \\
\hline Constant & $\begin{array}{c}-0.0384 * * * \\
(-3.469) \\
\end{array}$ & $\begin{array}{c}-0.0381 * * * \\
(-3.618) \\
\end{array}$ & $\begin{array}{c}-0.0338 * * * \\
(-3.249) \\
\end{array}$ \\
\hline \# Observations & 610 & 618 & 618 \\
\hline \# Countries & 156 & 156 & 156 \\
\hline Hansen Test & 0.300 & 0.441 & 0.256 \\
\hline AR (1) & 0.0491 & 0.0467 & 0.0286 \\
\hline AR (2) & 0.190 & 0.194 & 0.202 \\
\hline
\end{tabular}

Sources: see Table 1.

Notes:

- System-GMM estimations for dynamic panel-data models. Sample period: 1980-2010;

- All explanatory variables were treated as endogenous. Their lagged values were used as instruments in the first-difference equations and their lagged first-differences were used in the levels equation;

- Two-step results using robust standard errors corrected for finite samples.

- The government size proxy used is indicated in the top of the respective column;

- t-statistics are in parenthesis. Significance level at which the null hypothesis is rejected: $* * *, 1 \% ; * *, 5 \%$, and $*, 10 \%$. 
Table 3: Interactions with Dummies for Development and Income Levels

\begin{tabular}{|c|c|c|c|c|}
\hline VARIABLES & $\begin{array}{l}(1) \\
\text { UN }\end{array}$ & $\begin{array}{c}(2) \\
\text { PWT-kg }\end{array}$ & $\begin{array}{l}\text { (3) } \\
\text { UN }\end{array}$ & $\begin{array}{c}\text { (4) } \\
\text { PWT-kg }\end{array}$ \\
\hline $\log (\mathrm{HDI})(-1)$ & $\begin{array}{c}-0.0634 * * * \\
(-6.034)\end{array}$ & $\begin{array}{c}-0.0623 * * * \\
(-6.174)\end{array}$ & $\begin{array}{c}-0.0672 * * * \\
(-5.994)\end{array}$ & $\begin{array}{c}-0.0782 * * * \\
(-5.620)\end{array}$ \\
\hline Size of government*Developed & $\begin{array}{l}0.142 * \\
(1.665)\end{array}$ & $\begin{array}{l}0.122 * \\
(1.675)\end{array}$ & & \\
\hline$(\text { Size of government*Developed })^{2}$ & $\begin{array}{l}-0.408^{*} \\
(-1.728)\end{array}$ & $\begin{array}{l}-0.590^{*} \\
(-1.751)\end{array}$ & & \\
\hline Size of government*Developing & $\begin{array}{l}0.0301 \\
(0.323)\end{array}$ & $\begin{array}{l}-0.0326 \\
(-0.742)\end{array}$ & & \\
\hline$\left(\right.$ Size of government*Developing) ${ }^{2}$ & $\begin{array}{c}-0.120 \\
(-0.471)\end{array}$ & $\begin{array}{l}0.0359 \\
(0.357)\end{array}$ & & \\
\hline Size of government*High Income & & & $\begin{array}{l}0.112 * \\
(1.815)\end{array}$ & $\begin{array}{l}0.137 * \\
(1.724)\end{array}$ \\
\hline$\left(\right.$ Size of government*High Income) ${ }^{2}$ & & & $\begin{array}{l}-0.303 * \\
(-1.731)\end{array}$ & $\begin{array}{c}-0.815 * * \\
(-1.994)\end{array}$ \\
\hline Size of government*Low Income & & & $\begin{array}{l}-0.0385 \\
(-0.665)\end{array}$ & $\begin{array}{c}-0.0988 * * * \\
(-2.637)\end{array}$ \\
\hline$\left(\right.$ Size of government ${ }^{*}$ Low Income) ${ }^{2}$ & & & $\begin{array}{l}0.0384 \\
(0.208)\end{array}$ & $\begin{array}{c}0.197 * * * \\
(3.058)\end{array}$ \\
\hline Investment growth & $\begin{array}{c}0.0142 * * \\
(2.141)\end{array}$ & $\begin{array}{c}0.0165 * * * \\
(3.331)\end{array}$ & $\begin{array}{c}0.0121 * * \\
(2.396)\end{array}$ & $\begin{array}{c}0.0116^{* *} \\
(2.356)\end{array}$ \\
\hline Infant mortality & $\begin{array}{c}-0.000174 * * * \\
(-3.083)\end{array}$ & $\begin{array}{c}-0.000212 * * * \\
(-3.384)\end{array}$ & $\begin{array}{c}-0.000186 * * * \\
(-3.407)\end{array}$ & $\begin{array}{c}-0.000230 * * * \\
(-3.329)\end{array}$ \\
\hline Secondary school enrollment & $\begin{array}{c}0.000143 * * \\
\quad(2.538)\end{array}$ & $\begin{array}{c}8.26 \mathrm{e}-05^{*} \\
(1.731)\end{array}$ & $\begin{array}{c}0.000113 * * \\
(2.099)\end{array}$ & $\begin{array}{c}0.000164 * * * \\
(2.973)\end{array}$ \\
\hline Constant & $\begin{array}{c}-0.0355 * * * \\
(-3.355) \\
\end{array}$ & $\begin{array}{c}-0.0237 * * * \\
(-3.560)\end{array}$ & $\begin{array}{c}-0.0309 * * * \\
(-3.396)\end{array}$ & $\begin{array}{c}-0.0345 * * * \\
(-4.363)\end{array}$ \\
\hline \# Observations & 610 & 618 & 610 & 618 \\
\hline \# Countries & 156 & 156 & 156 & 156 \\
\hline Hansen Test & 0.113 & 0.473 & 0.311 & 0.299 \\
\hline AR (1) & 0.0904 & 0.0435 & 0.0864 & 0.0387 \\
\hline AR (2) & 0.191 & 0.190 & 0.195 & 0.199 \\
\hline
\end{tabular}

Sources: see Table 1.

Notes:

- System-GMM estimations for dynamic panel-data models. Sample period: 1980-2010;

- All explanatory variables were treated as endogenous. Their lagged values were used as instruments in the first-difference equations and their lagged first-differences were used in the levels equation. Period dummies were included;

- Two-step results using robust standard errors corrected for finite samples.

- The government size proxy used is indicated in the top of the respective column;

- t-statistics are in parenthesis. Significance level at which the null hypothesis is rejected: ***, 1\%; **, 5\%, and $*, 10 \%$. 
Table 4: Economic Development, Government Size and Economic Freedom

\begin{tabular}{|c|c|c|c|c|}
\hline & $(1)$ & (2) & (3) & (4) \\
\hline $\log (\mathrm{HDI})(-1)$ & $\begin{array}{c}-0.0597 * * * \\
(-5.753)\end{array}$ & $\begin{array}{c}-0.0596 * * * \\
(-5.100)\end{array}$ & $\begin{array}{c}-0.0647 * * * \\
(-5.368)\end{array}$ & $\begin{array}{c}-0.0740 * * * \\
(-6.028)\end{array}$ \\
\hline Size of government & $\begin{array}{l}0.272 * * \\
(2.250)\end{array}$ & $\begin{array}{l}0.257^{*} \\
(1.742)\end{array}$ & $\begin{array}{l}0.167^{*} \\
(1.851)\end{array}$ & $\begin{array}{l}0.272^{* *} \\
(2.078)\end{array}$ \\
\hline Size of government ${ }^{2}$ & $\begin{array}{c}-0.775 * * \\
(-2.271)\end{array}$ & $\begin{array}{l}-0.755^{*} \\
(-1.818)\end{array}$ & $\begin{array}{l}-0.510^{*} \\
(-1.923)\end{array}$ & $\begin{array}{c}-0.774 * * \\
(-2.119)\end{array}$ \\
\hline $\begin{array}{l}\text { Area 2: Legal structure and security } \\
\quad \text { of property rights }\end{array}$ & $\begin{array}{l}0.0126 * * * \\
(2.595)\end{array}$ & $\begin{array}{c}0.00733 \\
(1.264)\end{array}$ & $\begin{array}{c}0.000328 \\
(0.0430)\end{array}$ & $\begin{array}{c}0.00733 \\
(1.303)\end{array}$ \\
\hline Area 3: Access to sound money & $\begin{array}{c}-0.00023 * * * \\
(-3.973)\end{array}$ & $\begin{array}{l}-0.00021 * * * \\
(-3.294)\end{array}$ & $\begin{array}{c}-0.00023 * * * \\
(-4.102)\end{array}$ & $\begin{array}{c}-0.00027 * * * \\
(-4.662)\end{array}$ \\
\hline $\begin{array}{l}\text { Area 4: Freedom to trade } \\
\text { internationally }\end{array}$ & $\begin{array}{c}0.000131^{* *} \\
(2.456)\end{array}$ & $\begin{array}{c}0.000139 * * \\
(2.191)\end{array}$ & $\begin{array}{l}0.000156^{* * * *} \\
(2.977)\end{array}$ & $\begin{array}{l}0.000212 * * * \\
\quad(3.622)\end{array}$ \\
\hline $\begin{array}{l}\text { Area 5: Regulation of credit, labor, } \\
\text { and business }\end{array}$ & $\begin{array}{r}2.64 \mathrm{e}-05 \\
(0.0414)\end{array}$ & & & \\
\hline Investment growth & & $\begin{array}{c}0.00125^{*} \\
(1.903)\end{array}$ & & \\
\hline Infant mortality & & & $\begin{array}{l}0.00183 * * \\
(2.113)\end{array}$ & \\
\hline Secondary school enrollment & & & & $\begin{array}{l}0.00197 * * \\
(1.984)\end{array}$ \\
\hline Constant & $\begin{array}{c}-0.0444 * * * \\
(-3.720)\end{array}$ & $\begin{array}{c}-0.0541 * * * \\
(-3.243)\end{array}$ & $\begin{array}{c}-0.0509 * * * \\
(-4.022)\end{array}$ & $\begin{array}{c}-0.0687 * * * \\
(-3.520)\end{array}$ \\
\hline \# Observations & 504 & 517 & 496 & 515 \\
\hline \# Countries & 114 & 115 & 114 & 115 \\
\hline Hansen Test & 0.779 & 0.216 & 0.510 & 0.778 \\
\hline AR (1) & 0.0411 & 0.115 & 0.119 & 0.0868 \\
\hline AR (2) & 0.155 & 0.192 & 0.434 & 0.226 \\
\hline
\end{tabular}

Sources: see Table 1.

Notes:

- System-GMM estimations for dynamic panel-data models. Sample period: 1980-2010;

- All explanatory variables were treated as endogenous. Their lagged values were used as instruments in the first-difference equations and their lagged first-differences were used in the levels equation. Period dummies were included;

- Two-step results using robust standard errors corrected for finite samples.

- The government size proxy was that of the United Nation database;

- $\quad$-statistics are in parenthesis. Significance level at which the null hypothesis is rejected: ***, $1 \%$; **, 5\%, and $*, 10 \%$. 
Table 5: Composition of Public Expenditure and Economic Development

\begin{tabular}{|c|c|c|c|c|c|}
\hline & $(1)$ & (2) & (3) & (4) & $(5)$ \\
\hline $\log (\mathrm{HDI})(-1)$ & $\begin{array}{c}-0.0369 * * * \\
(-8.045)\end{array}$ & $\begin{array}{c}-0.0376 * * * \\
(-6.881)\end{array}$ & $\begin{array}{c}-0.0409 * * * \\
(-6.311)\end{array}$ & $\begin{array}{c}-0.0369 * * * \\
(-4.418)\end{array}$ & $\begin{array}{c}-0.0349 * * * \\
(-5.430)\end{array}$ \\
\hline Defense (\% T.Expense) & $\begin{array}{c}0.00809 \\
(0.624)\end{array}$ & & & & \\
\hline Health (\% T.Expense) & & $\begin{array}{r}0.0162 * \\
(1.710)\end{array}$ & & & \\
\hline Education (\% T.Expense) & & & $\begin{array}{l}-0.0138 \\
(-1.303)\end{array}$ & & \\
\hline $\begin{array}{c}\text { Social Protection (\% } \\
\text { T.Expense) }\end{array}$ & & & & $\begin{array}{l}0.00591 \\
(0.590)\end{array}$ & \\
\hline Rest (\% T.Expense) & & & & & $\begin{array}{c}0.000304 \\
(0.0388)\end{array}$ \\
\hline Investment growth & $\begin{array}{l}0.00922 * * \\
(2.048)\end{array}$ & $\begin{array}{l}0.00870^{* *} \\
(2.203)\end{array}$ & $\begin{array}{c}0.0113 * * * \\
(3.140)\end{array}$ & $\begin{array}{c}0.0111^{* *} \\
(2.504)\end{array}$ & $\begin{array}{l}0.00996 * * \\
(2.334)\end{array}$ \\
\hline Infant mortality & $\begin{array}{c}-0.00012 * * * \\
(-3.172)\end{array}$ & $\begin{array}{c}-0.00011 * * \\
(-2.309)\end{array}$ & $\begin{array}{c}-0.0001 * * * \\
(-3.367)\end{array}$ & $\begin{array}{c}-0.00011^{*} \\
(-1.950)\end{array}$ & $\begin{array}{c}-0.00011^{* *} \\
(-2.151)\end{array}$ \\
\hline $\begin{array}{c}\text { Secondary school } \\
\text { enrollment }\end{array}$ & $\begin{array}{l}6.23 \mathrm{e}-05 \\
(1.503)\end{array}$ & $\begin{array}{c}6.94 \mathrm{e}-05^{*} \\
(1.809)\end{array}$ & $\begin{array}{c}6.20 \mathrm{e}-05 \\
(1.477)\end{array}$ & $\begin{array}{l}4.19 \mathrm{e}-05 \\
(1.093)\end{array}$ & $\begin{array}{l}5.64 \mathrm{e}-05^{*} \\
(1.704)\end{array}$ \\
\hline Constant & $\begin{array}{c}-0.0112 * * \\
(-2.155)\end{array}$ & $\begin{array}{c}-0.0139 * * * \\
(-2.578) \\
\end{array}$ & $\begin{array}{c}-0.0106^{* *} \\
(-2.050) \\
\end{array}$ & $\begin{array}{c}-0.0111^{* *} \\
(-1.999) \\
\end{array}$ & $\begin{array}{c}-0.0101 * * \\
(-1.981) \\
\end{array}$ \\
\hline \# Observations & 237 & 237 & 237 & 237 & 237 \\
\hline \# Countries & 79 & 79 & 79 & 79 & 79 \\
\hline Hansen Test & 0.571 & 0.379 & 0.582 & 0.556 & 0.505 \\
\hline AR (1) & 0.208 & 0.181 & 0.188 & 0.198 & 0.203 \\
\hline $\mathrm{AR}(2)$ & 0.458 & 0.594 & 0.442 & 0.492 & 0.432 \\
\hline
\end{tabular}

Sources: see Table 1.

Notes:

- System-GMM estimations for dynamic panel-data models. Sample period: 1980-2010;

- All explanatory variables were treated as endogenous. Their lagged values were used as instruments in the first-difference equations and their lagged first-differences were used in the levels equation. Period dummies were included;

- Two-step results using robust standard errors corrected for finite samples.

- t-statistics are in parenthesis. Significance level at which the null hypothesis is rejected: ***, 1\%; **, 5\%, and $*, 10 \%$ 
Table 6: Composition of Public Expenditure and Economic Development

\begin{tabular}{|c|c|c|c|c|c|}
\hline & (1) & (2) & (3) & (4) & $(5)$ \\
\hline $\log (\mathrm{HDI})(-1)$ & $\begin{array}{c}-0.0341 * * * \\
(-7.259)\end{array}$ & $\begin{array}{c}-0.0460 * * * \\
(-6.744)\end{array}$ & $\begin{array}{c}-0.0442 * * * \\
(-7.873)\end{array}$ & $\begin{array}{c}-0.0394 * * * \\
(-4.610)\end{array}$ & $\begin{array}{c}-0.0445 * * * \\
(-7.807)\end{array}$ \\
\hline Defense (\% T.Expense) & $\begin{array}{c}0.0478 * \\
(1.924)\end{array}$ & & & & \\
\hline Defense (\% T.Expense) $)^{2}$ & $\begin{array}{l}-0.172 * * \\
(-2.470)\end{array}$ & & & & \\
\hline Health (\% T.Expense) & & $\begin{array}{c}-0.0810 * * \\
(-2.194)\end{array}$ & & & \\
\hline Health (\% T.Expense $)^{2}$ & & $\begin{array}{c}0.329 * * \\
(2.105)\end{array}$ & & & \\
\hline Education (\% T.Expense) & & & $\begin{array}{l}0.0872 * \\
(1.704)\end{array}$ & & \\
\hline Education (\% T.Expense) $)^{2}$ & & & $\begin{array}{l}-0.381^{*} \\
(-1.728)\end{array}$ & & \\
\hline $\begin{array}{c}\text { Social Protection (\% } \\
\text { T.Expense) }\end{array}$ & & & & $\begin{array}{l}0.0437 * \\
(1.874)\end{array}$ & \\
\hline $\begin{array}{c}\text { Social Protection (\% } \\
\text { T.Expense) }\end{array}$ & & & & $\begin{array}{c}-0.0826 * * \\
(-2.025)\end{array}$ & \\
\hline Rest (\% T.Expense) & & & & & $\begin{array}{l}-0.0457 * \\
(-1.793)\end{array}$ \\
\hline Rest (\% T.Expense) $)^{2}$ & & & & & $\begin{array}{c}0.0463^{*} \\
(1.904)\end{array}$ \\
\hline Investment growth & $\begin{array}{l}0.0105^{*} \\
(1.865)\end{array}$ & $\begin{array}{c}0.0145^{* * * *} \\
(4.132)\end{array}$ & $\begin{array}{l}0.0139 * * * \\
(3.522)\end{array}$ & $\begin{array}{c}0.00764 \\
(1.121)\end{array}$ & $\begin{array}{l}0.0135^{* * * *} \\
(2.696)\end{array}$ \\
\hline Infant mortality & $\begin{array}{l}-7.56 \mathrm{e}-05^{* *} \\
(-1.963)\end{array}$ & $\begin{array}{c}-0.00018 * * * \\
(-4.131)\end{array}$ & $\begin{array}{c}-0.00015^{* * *} \\
(-3.407)\end{array}$ & $\begin{array}{c}-0.00012 * * \\
(-2.439)\end{array}$ & $\begin{array}{c}-0.00017 * * * \\
(-5.140)\end{array}$ \\
\hline $\begin{array}{l}\text { Secondary school } \\
\text { enrollment }\end{array}$ & $\begin{array}{l}8.68 \mathrm{e}-05^{* *} \\
(2.126)\end{array}$ & $\begin{array}{c}0.000107 * * * \\
(3.084)\end{array}$ & $\begin{array}{l}9.17 \mathrm{e}-05^{*} \\
(1.950)\end{array}$ & $\begin{array}{c}0.000120 * * * \\
(2.750)\end{array}$ & $\begin{array}{c}9.73 \mathrm{e}-05^{* * * *} \\
(2.726)\end{array}$ \\
\hline Constant & $\begin{array}{c}-0.0152 * * * \\
(-3.297)\end{array}$ & $\begin{array}{c}-0.0134 * * * \\
(-2.627) \\
\end{array}$ & $\begin{array}{c}-0.0195 * * * \\
(-3.907)\end{array}$ & $\begin{array}{c}-0.0207 * * * \\
(-3.137) \\
\end{array}$ & $\begin{array}{c}-0.00581 \\
(-0.980) \\
\end{array}$ \\
\hline \# Observations & 237 & 237 & 237 & 237 & 237 \\
\hline \# Countries & 79 & 79 & 79 & 79 & 79 \\
\hline Hansen Test & 0.508 & 0.795 & 0.380 & 0.354 & 0.472 \\
\hline AR (1) & 0.226 & 0.201 & 0.137 & 0.261 & 0.157 \\
\hline AR (2) & 0.408 & 0.190 & 0.459 & 0.469 & 0.343 \\
\hline
\end{tabular}

Sources: see Table 1.

Notes:

- System-GMM estimations for dynamic panel-data models. Sample period: 1980-2010;

- All explanatory variables were treated as endogenous. Their lagged values were used as instruments in the first-difference equations and their lagged first-differences were used in the levels equation. Period dummies were included;

- Two-step results using robust standard errors corrected for finite samples.

- t-statistics are in parenthesis. Significance level at which the null hypothesis is rejected: ***, $1 \%$; **, 5\%, and $*, 10 \%$ 


\section{Most Recent Working Paper}

NIPE WP $\quad$ Martins, Susana e Francisco José Veiga, "Government size, composition of public expenditure,

17/2013 and economic development", 2013

NIPE WP Bastos, Paulo e Odd Rune Straume, "Preschool education in Brazil: Does public supply crowd

16/2013 out private enrollment?", 2013

NIPE WP Martins, Rodrigo e Francisco José Veiga, "Does voter turnout affect the votes for the incumbent

15/2013 government?", 2013

NIPE WP Aguiar-Conraria, Luís, Pedro C. Magalhães e Christoph A. Vanberg, "Experimental evidence

$14 / 2013$ that quorum rules discourage turnout and promote election boycotts", 2013

NIPE WP Silva, José Ferreira, J. Cadima Ribeiro, “As Assimetrias Regionais em Portugal: análise da

13/2013 convergência versus divergência ao nível dos municípios”, 2013

NIPE WP Faria, Ana Paula, Natália Barbosa e Vasco Eiriz, "Firms' innovation across regions: an

12/2013 exploratory study", 2013

NIPE WP Veiga, Francisco José, “Instituições, Estabilidade Política e Desempenho Económico

11/2013 Implicações para Portugal”, 2013

NIPE WP Barbosa, Natália, Ana Paula Faria e Vasco Eiriz, "Industry- and firm-specific factors of

10/2013 innovation novelty", 2013

NIPE WP Castro, Vítor e Megumi Kubota, "Duration dependence and change-points in the likelihood of

09/2013 credit booms ending", 2013

NIPE WP Monteiro, Natália Pimenta e Geoff Stewart "Scale, Scope and Survival: A Comparison of

08/2013 Cooperative and Capitalist Modes of Production", 2013

NIPE WP Esteves, Rosa-Branca e Joana Resende, "Competitive Targeted Advertising with Price

07/2013 Discrimination", 2013

NIPE WP Barbosa, Natália, Maria Helena Guimarães e Ana Paula Faria, "Single Market non-

06/2013 compliance: how relevant is the institutional setting?", 2013

NIPE WP Lommerud, Kjell Erik, Odd Rune Straume e Steinar Vagstad, "Mommy tracks and public

05/2013 policy: On self-fulfilling prophecies and gender gaps in promotion”, 2013

NIPE WP Brekke, Kurt R., Luigi Siciliani e Odd Rune Straume, "Hospital Mergers: A Spatial

04/2013 Competition Approach”, 2013

NIPE WP Faria, Ana Paula e Natália Barbosa, “Does venture capital really foster innovation?”, 2013

$03 / 2013$

NIPE WP

$02 / 2013$

NIPE WP

$01 / 2013$

Esteves, Rosa Branca, “Customer Poaching with Retention Strategies”, 2013

NIPE WP

27/2012

Aguiar-Conraria, Luís, Teresa Maria Rodrigues e Maria Joana Soares, "Oil Shocks and the Euro as an Optimum Currency Area”, 2013

NIPE WP Sushanta K. Mallick e Ricardo M. Sousa, "Is Technology Factor-Neutral? Evidence from the US

26/2012

NIPE WP

$25 / 2012$

NIPE WP

24/2012

NIPE WP

23/2012

NIPE WP

22/2012

NIPE WP

21/2012

NIPE WP

20/2012

Ricardo M. Sousa, "The Effects of Monetary Policy in a Small Open Economy: The Case of

Portugal" 2012

Manufacturing Sector" 2012

Jawadi, F. e Ricardo M. Sousa, "Structural Breaks and Nonlinearity in US and UK Public Debt" 2012

NIPE WP

$19 / 2012$

Jawadi, F. e Ricardo M. Sousa, "Consumption and Wealth in the US, the UK and the Euro Area:

A Nonlinear Investigation” 2012

Jawadi, F. e Ricardo M. Sousa, “ Modelling Money Demand: Further Evidence from an

International Comparison" 2012

Jawadi, F. e Ricardo M. Sousa, " Money Demand in the euro area, the US and the UK:

Assessing the Role of Nonlinearity" 2012

Agnello, L, Sushanta K. Mallick e Ricardo M. Sousa, "Financial Reforms and Income

Inequality" 2012

Agnello, L, Gilles Dufrénot e Ricardo M. Sousa, "Adjusting the U.S. Fiscal Policy for Asset

Prices: Evidence from a TVP-MS Framework t" 2012

Agnello, L e Ricardo M. Sousa, "Fiscal Adjustments and Income Inequality: A First

Assessment" 2012 